\title{
Pemukiman Elite Kesultanan Deli
}

\author{
Oleh: \\ Y u s h a r
}

\begin{abstract}
ABSTRAK
Telaah ini bertujuan untuk mengetahui terbentuknya Kota Matsum di Kesultanan Deli,menelisik aktivitas masyarakat di bidang sosial,politik. Telaah ini adalah kajian historik dengan menggunakan model deskriptif kualitatif. Metode yang digunakan adalah studi lapangan(Field Research)dengan metode observasi dan wawancara dengan narasumber yang dikonfirmasi dengan studi pustaka (Library research), Hasil telaah diketahui bahwa Kota Maksum merupakan kawasan pemukiman bagi rakyat Kesultan terutama kalangan bangsawan serta pejabat Kerajaan Deli.Sebagian besar masyarakat Kota Maksum terdiri dari orang-orang kelas sosial menengah ke atas dengan status sosial ekonomi tinggi.Aktivitas budaya di Kota Maksum dapat dilihat dari upacara-upacara adat di Istana Maimoon. Dalam acara-acara besar biasanya diadakan pula pesta rakyat berupa kesenian dan pasar malam. Masyarakat Kota Maksum tunduk kepada undang-undang sultan dengan penegak hukumnya berupa lembaga peradilan dan polisi swapraja.Kehidupan bangsawan di Kota Maksum berakhir dengan peristiwa revolusi sosial 1946 berikut dihapuskannya sistem kerajaan dengan cara di luar batas perikemanusiaan dalam ujud penjarahan dan pembakaran rumah-rumah bangsawan.
\end{abstract}

Kata Kunci : Kota Maksum, kehidupan masyarakat,revolusi 


\section{PENDAHULUAN}

Kota Maksum merupakan pemukiman yang berada dalam kota Medan yang penghuninya adalah kerabat kerajaan para bangsawan Deli yang memiliki hak privilage sebagai kelas sosial tinggi sehingga menampilkan gaya hidup yang eksklusif dan mempunyai magnet tersendiri untuk ditelaah .Sebagai pemukiman yang dihuni oleh kelas sosial atas masyarakat Melayu Deli sekaligus kawasan pusat penyelenggaraan organisasi pemerintahan. Kampung ini menampilkan wajah sosial budaya yang cenderung tertutup bagi masyarakat luar bangsawan Deli.Pertumbuhan Medan dimulai sejak Jacobus Nienhuys memindahkan kantor kebunnya ke Medan Putri pada 1869, Medan yang semulanya sepi sebagai kawasan pemukiman masyarakat lokal, mulai menjadi kawasan yang ramai berikut kehadiran para pendatang.Dipilihnya Medan Putri berdasarkan pertimbangan letaknya yang strategis, yaitu berada di dataran yang lebih tinggi sehingga tidak mudah kebanjiran di musim hujan dan yang terpenting berada di tengah-tengah pusat perkebunan.

Kota Medan sendiri,dalam bahasa Melayu berarti tempat berkumpul,arena tempat berinteraksi dan berkomunikasi,gelanggang tempat pertunjukan dan keramaian.Pengertian ini berkembang sejalan pertumbuhan dan perkembangan kawasan ini sehingga dijadikan sebagai tempat untuk membongkar muatan kapal dan tongkang yang masuk menelusuri Sei Deli dari pelabuhan Belawan menuju pedalaman. Kapal-kapal ini memindahkan dan membongkar muatannya ke kapal atau perahu kecil untuk kemudian meneruskan ke daerah Deli Tua dan daerah lainnya di hulu Sei Deli. Medan juga menjadi tempat berdagang bagi orang-orang dari Hamparan Perak, Sukapiring,Sunggal,Gelugur,Kota Bangun.

Medan tumbuh menjadi tempat interaksi berbagai golongan masyarakat sehingga kemudian menjadi alasan dipindahkannya ibukota Residen Sumatera Timur dan pusat pemerintahan Kesultanan Deli ke Medan.Pemerintahan Kesultanan Deli masa ini dipegang oleh Sultan Makmun Alrasyid Perkasa Alamsyah, beliau dijuluki sebagai tokoh pembangun kota Medan. Sebelum Kota Maksum menjadi daerah pemukiman ,raja beserta kerabat dan rakyatnya, lebih dulu membangun istana Maimoon dengan peletakan batu pertama pada 1888. Keluarga 
kerajaan pindah ke sana dari istana Labuhan pada 1891 sebelum akhirnya mendiami istana Puri yang mulai dibangun pada 1905.terletak di Kota Maksum

Dilihat dari komposisi sosial,masyarakat Kota Maksum dihuni oleh etnis pribumi suku Melayu, Jawa, Mandailing dan Minangkabau yang merupakan konsekwensi terbentuknya pemukiman dari pencampuran tersebut, masyarakat yang tinggal di Kota Maksum menjadi lancar berbahasa Melayu dengan dialeg yang masih kental dengan bahasa asal.Sebagai daerah yang dihuni oleh kalangan Bangsawan Melayu, maka tidak heran jika arsitektur bernuansa Melayu di Kota Maksum sebagian besar merupakan rumah panggung yang terbuat dari kayu. Kawasan ini banyak dihuni oleh pejabat kerajaan yang turut berkontribusi dalam kehidupan politik kesultanan Deli. Hukum Sultan merupakan hukum yang berlandaskan pada agama Islam. Maka dalam kebijakan, keputusan maupun penegakan hukumnya, kesultanan Deli dibantu oleh penasehat dalam bagian hukum-hukum Islam.

Untuk merekonstruksi kawasan ini sebagai pemukiman elite ada beberapa persoalan dalam kajian ini antara lain adalah bagaimana terbentuknya Kota Maksum sebagai pemukiman elit serta apa saja aktivitas kehidupan sosial, politik,masyarakat Kota Maksum.Untuk mengurai masalah ini dirancang penelitian deskriptif kualitatif dengan menggunakan metode studi Lapangan (Field Research) yang dikombinasikan dengan Studi pustaka (Library Research) melalui langkah-heuristik untuk mendapatkan data yang valid seraya melakukan verifikasi atas data tersebut untuk kemudian diklassifikasikan agar terpilih data yang paling cocok dengan tema agar dalam historiografi tersaji uraian yang faktual dan historik

\section{PEMBAHASAN}

\section{A .Pemukiman Elite Kesultanan Deli}

Kawasan yang dimaksud dalam ulasan ini terletak memanjang antara Jl.Raja/Singamangaraja dari makam Pahlawan di sebelah Selatan jl.Utama ke Utara sampai Jl.Japaris/Jl.Rahmadsyah depan kolam renang Paradiso.Ke arah Timur sampai Jl.Laksana dari Selatan Jl.Utama ke Utara J1.Japaris/J1.Rahmadsyah. Di antara kedua sisi Utara dan Selatan membentang jalan dari Timur ke Barat J1.Amaliun,Jl.PuriKawasan ini sejatinya merupakan 
pemukiman Melayu dari rakyat kebanyakan sampai bangsawan tinggi, wilayah ini hanya tempat bermukim saja,tidak seperti daerah elit lainnya seperti di Jawa. Kalau di Ngayokyakarta kita mengenal Kota Gede sebagai daerah eksklusif Kesultanan Mataram,maka akan ditemukan berbagai lokasi yang menjadi tempat aktivitas masyarakat sehari-hari.Ada pasar ada alun-alun ada Masjid yang menjadi ikon istana sebagai symbol mikrokosmos.Demikian juga Kasunanan Surakarta lengkap dengan institusi yang menunjukkan seksistensinya sebagai pusat pemerintahan dan interaksi masyarakat,sentana dalem berada di lingkukngan Istana dengan segala aktivitasnya.

Model pemukiman seperti ini sejatinya dicoba juga di Medan sebagai pusat pemerintahan Deli,walaupun tidak persis sama namun ada upaya untuk membangun kawasan yang khusus bagi kerabat Kesultanan, misalnya ada Istana,Masjid Raya,Taman Sari namun minus pasar .

Kota Maksum merupakan kota lama tempat Sultan Deli beserta keluarga dan kerabatnya tinggal. Sebelum menjadi sebuah pemukiman, pusat pemerintahan kesultanan Deli berada di Labuhan. Setidaknya ada dua alasan mengapa Sultan Makmun Al Rasyid memutuskan untuk memindahkan ibukota kesultanan Deli ke Medan. Alasan utama mengapa perpindahan ini terjadi adalah karena alasan geografis labuhan yang merupakan dataran rendah sehingga rawan terkena banjir di musim hujan. Sama seperti Kesultanan Langkat yang juga memindahkan pusat pemerintahannya dari Tanjung Pura ke Stabat karena alasan serupa.

Namun tidak bisa di pungkiri bahwa kehadiran Belanda dan pembukaan perkebunan di Sumatera Timur, khususnya di Medan dan sekitarnya menawarkan peluang ekonomi dan kemakmuran yang lebih besar daripada Labuhan. Hal ini setidaknya dapat dijadikan alasan yang lebih kuat bagi Sultan memindahkan pusat pemerintahannya walaupun beliau baru saja membangun istana baru tahun $1886 \mathrm{di}$ Labuhan Perlu diingat bahwa pada masa kolonial wilayah pemerintahan di Hindia Belanda dibagi menjadi dua. Yang pertama adalah wilayah langsung Hindia Belanda (untuk kasus di Medan adalah Gemeente) dan wilayah kerajaan bumiputra (Zelfbestuurende Landschappen) yang diikat dengan kontrak politik dan pernyataan pendek. Kesultanan Deli merupakan kerajaan yang diikat dengan politik kontrak dengan Kota Maksum sebagai daerah Ibukota atau Zelfbestuur milik Sultan. 
Jejak Kota Maksum sebagai sebuah pemukiman didirikan pada tahun 1905 yang ditandai dengan dibangunnya istana Puri pada 12 November 1905.Kota Maksum berfungsi sebagai kawasan pemukiman bagi sultan berserta keluarganya (istana puri), rumah-rumah bangsawan, pegawai pemerintahan serta rakyat Kesultanan. Urusan pemerintahan dan acara Kesultanan dilakukan di Istana Maimoon,Jika di tinjau dari ciri-ciri utama sebuah kota tradisional seperti yang umum ditemukan di Jawa masa kesultanan yaitu terdapat pusat pemerintahan , pusat ekonomi (pasar), pusat keagamaan (mesjid) dan alun-alun, maka kawasan Kota Maksum tidak memiliki sarana itu secara terpusat.Rumah ibadah yang dekat dengan istana dan taman sari .Pasar dan alun -alun letaknya berjauhan dari istana.Kota Maksum hanya berfungsi sebagai kawasan pemukiman sultan, bangsawan serta rakyatnya. Penamaan "kota" pada kawasan ini merujuk pada bangunan-bangunan elit yang menjadi tempat tinggal para keluarga kerajaan dengan segala kemegahan bangunannya masa itu yang memenuhi indikator sebuah kota.Namun, jika kota Maksum dan kawasan Sukaraja digabungkan secara keselurahan sebagai kawasan ibukota kesultanan Deli, maka terlihatlah ciri-ciri sebuah kota tradisional, dengan istana Maimoon sebagai pusat pemerintahan dengan alun-alun di hadapannya dan mesjid raya Al-Mansun sebagai pusat keagamaan dengan taman Sri Deli di seberang jalan menghadap utara .,hanya kita tidak menemukan pasar sebagai pusat kegiatan perekonomian masayarakat seperti di Jawa

Dengan demikian, Kota Maksum adalah contoh pemukiman tradisional yang mulai mengadopsi gaya kolonial, meninggalkan pola pemukiman yang berdiri di pinggir sungai. Belanda menyebut kawasan Kota Maksum sebagai Sultanground, ini terlihat dari peta Gemeete Medan buatan tahun 1919. kawasan yang berada di bawah naungan sultan disebut sebagai Sultanground. Secara geografis, tidak ada pemisahan berarti antara daerah sultan dan Gemeente jika dilihat dalam peta-peta Medan buatan Belanda. Maka Gemeente Medan dan Sultanground Kota Maksum adalah dua kawasan berdampingan yang menjadi pembentuk utama kota Medan sekarang ini.

Nama Kota Maksum diambil dari bahasa Arab, artinya terpelihara oleh dosa. Banyak yang beranggapan asal mula penamaan "Maksum" diambil dari nama 
Mufti Kerajaan Deli atau Ulama besar Syekh Hassan Maksum yang dulu pernah tinggal di kawasan ini, tepatnya di jalan Puri. Namun, sepertinya kabar tersebut tidak dapat dibuktikan karena keluarga Syekh Hasan Maksum pindah dari Labuhan ke Medan pada tanggal 22 Jumadilawal 1335-H bertepatan dengan tanggal 15 Maret 1917 Sementara Kota Maksum berdiri tahun 1905. Tidak pasti mengapa kawasan tersebut diberi nama Maksum yang kebetulan sama dengan nama seorang ulama besar kesultanan Deli. Secara etimologi penamaan ini memberi kesan yang pasti bahwa kawasan yang dihuni oleh para bangsawan ini adalah wilayah yangi "terpelihara" sebagai tempat tinggal yang yang suci, dan dihuni oleh orang-orang penting sebagai khalifah,apalagi kawasan ini bebas dari orang asing maupun Timur Jauh ..

\section{B. Aktivitas Sosial Masyarakat Kota Maksum}

Masyarakat Kota Maksum bukan anya dihuni oleh msyarakat Melayu ada juga etnis Mandailing, Minangkabau,Jawa. Orang-orang Mandailing banyak menjadi ulama-ulama atau guru agama. mereka yang lulus dari madrasah dipekerjakan oleh Sultan Deli sebagai Kadhi dan Imam serta jabatan-jabatan lain dalam pengadilan agama sehingga diberikan tanah dan rumah di Kota Maksum, Sungai Mati, Kampung Mesjid dan Gelugur. Orang Minangkabau sendiri berpindah ke Kota Maksum dari tahun 1920-an dengan menyewa rumah dari orang-orang suku Melayu dan Mandailing karena saat itu Sultan tidak mengizinkan mereka menjual rumahnya kepada kelompok etnik lain,terutama China dan Toba .Aktivitas sosial berjalan dalam irama yang statis karena kawasan ini relatip homogen dalam pemaknaan hanya menampilkan suasana Melayu dengan kiblat kegiatan adalah istana.yang kadang kala diselingi oleh keikut sertaan para penguasa kolonial sebagai mitra Kesultanan.

Setelah revolusi sosial orang Minangkabau mulai membeli rumah dan tanah dari orang-orang Melayu yang bermukim di kawasan ini kebanyakan adalah keluarga dan keturunan bangsawan. Orang Melayu menguasai tanah yang luas dan memiliki harta dalam bentuk rumah.Satu persatu harta milik mereka para bangsawan di lepas dengan jalan jual beli kepada masyarakat pendatang yang umumnya adalah orang Minangkabau dengan penghidupan berdagang,orang 
Mandailing yang menjadi pegawai Kerajaan,cerdik pandai dan pengajar sehingga secara perkahan dan pasti masyarakat Melayu tergerus dari wilayah yang enandai adanya hak verifilage mereka setalah percahnya revolusi sosial.Masyarakat Melayu dari kelompok elit sosial ini berdiaspora ke berbagai daerah yang ada di kawasan Medan menjadi rakyat biasa karena takut dengan stigma sebagai feodal anti Republikan. Penghapusan atau penyembunyian identitas sebagai etnis yang berkelas sosial sesuai dengan masyarakat Melayu menjadi hilang dan ini adalah suatu malapetaka bagi etnis dalam tragedi peradaban yang lazim disebut sebagai revolusi sosial.Lebih satu generasi mereka menyebunyikan identitas sosialnya.

\section{C . Kehidupan Politik Masyarakat Kota Maksum}

Pada hakekatnya sebagai bagian dari pemerintahan yang bermitra dengan pemerintah kolonial terutama masa Sultan Makmun Al-Rasyid, disusun kaedahkaedah yang diperlukan dalam penyelenggaraan pemerintahan, ekonomi, sosial bagi masyarakatnya. Sejauh tidak bertentangan dngan hukum yang diberlakukan dalam politik kontrak. Hukum yang dibentuk didasarkan kepada hukum adat dan Islam. Untuk penegakan hukumnya, kesultanan Deli memiliki beberapa lembaga penting yaitu LembagaPeradilan (Mahkamah Kerapatan yang berada di jalan Pemuda seberang Timur Istana Maimon yang sekarang telah menjadi semak belukar,gedungnya telah di hancurkan zaman Walikota A.S.Rangkuti) dan Institusi Kepolisian Swapraja. Hukum yang dibuat sultan merupakan putusan politik untuk kepentingan kekuasaan yang berkaitan dengn masyarakat Melayu semata yang secara aplikasi permasalahannya diselesaikan dari kepala kampung, jika tidak selesai maka akan dinaikkan ke Kerapatan ro 1. Kerapatan ro 1 ada di kota Medan yang diketuai oleh Temenggung dan atau Bendahara.Lembaga ini diperuntukkan kepada penduduk kampung Kota Maksum, Gelugur, Sukaramai, Pulau Berayan dan Tanjung Mulia.

Selain sebagai kepala pemerintahan, Sultan juga menjabat sebagai Ulil Amri (Pelindung orang beriman) dalam urusan atau masalah yang berhubungan dengan agama Islam, Sultan didampingi oleh seorang ulama yang paling terkemuka di kerajaannya yang sering disebut sebagai Imam Paduka Tuan atau Mufti Kerajaan. Mufti kerajaan Deli yang sangat termahsyur adalah Syekh Hassan Maksum, ia 
merupakan penasihat untuk urusan-urusan yang menyangkut agama Islam. Jika sidang dalam kerapatan besar membutuhkan pendangannya dalam mencapai putusan, maka akan dikirimkan surat padanya dan jawabannya dibacakan di dalam sidang kerapatan..Akan tetapi status rakyat raja dan rakyat Gubernemen yang berbeda penanganan hukumnya membuat Veldpolitie ragu-ragu memberikan bantuan jika ada masalah perundang-undangan. Banyak hukum-hukum yang bertentangan antara Swapraja dan Kotapraja, misalnya rapat-rapat tertutup yang bersifat politik merupakan suatu pelanggaran di dalam wilayah Swapraja, namun tidak di dalam kawasan Gubernemen. Contoh lain adalah masalah perkawinan antara laki-laki biasa dan perempuan bangsawan merupakan tindak pidana di dalam Swapraja. Penanganan hukum menjadi sulit ketika pasangan tersebut melarikan diri ke wilayah Gubernemen yang tidak melarang pernikahan tersebut.

Minimnya kekuatan keamanan Swapraja Deli diulas dalam berita koran Sinar Deli tertanggal 7 September 1932. Berita itu mengabarkan kunjungan maharaja Kapurthala dari India untuk melihat Deli. Ia membandingkan balatentara dan polisi di Swapraja negerinya dengan polisi Swapraja Deli yang sangat minim. Jumlah polisi Swapraja yang sangat sedikit tidak bisa memenuhi kebutuhan keamanan di perkampungan sultan yaitu Kota Maksum. Sultan Amaluddin yang berkuasa saat itu melarang orang-orang Tionghoa untuk masuk ke Kota Maksum untuk berdagang. Untuk itu dikerahkan polisi untuk berjaga-jaga di jalan-jalan masuk. Namun polisi-polisi ini sering kali kecolongan karena jumlah mereka yang sedikit tidak mampu membendung masuknya orang-orang Tionghoa dari berbagai arah. Penegakan hukum untuk orang-orang Tionghoa ini juga tidak bisa dilaksanakan karena mereka masuk ke dalam rakyat Gubernemen yang berada dibawah hukum Hindia Belanda.Seringkali orang-orang Tionghoa ini dapat bebas dari hukuman karena ketidaksesuaian hukum antara dua kawasan tersebut.Dengan keadaan tersebut, aktivitas politik sultan bagi masyarakatnya baik itu di Kota Maksum maupun daerah-daerah sultan yang lain tidak dapat berjalan sepenuhnya sesuai dengan yang telah ditentukan. Hal ini dikarenakan adanya Belanda yang dari dalam mempengaruhi kebijakan sultan dan membatasi undang-undang dan ketetapannya di wilayah wewenangnya, dan dari luar menciptakan keadaan yang 
memperlemah kekuatan hukum swapraja dengan ketidaksesuaian-ketidaksesuaian hukum dan penanganannya antara Gemeente dan Swapraja.

\section{Aktivitas Budaya Masyarakat Kota Maksum}

Dari segi budaya, Masyarakat Kota Maksum menunjukkan identitas Melayu yang lebih dominan di masyarakat Kota Maksum dengan ciri bahasa Melayu sebagai bahasa sehari-hari dengan logat yang khas dari bahasa ibunya. hanya dengan sesama sukunya saja mereka berbicara dengan bahasa asalnya. Dari segi bangunan, telah ada pengaruh budaya asing pada bangunan-bangunan yang ada di Kota Maksum, seperti penggunaan bahan dasar beton sehingga telah menyerupai bangunan semi permanen. Seperti halnya Istana Puri yang menunjukkan arsitektur rumah panggung khas Melayu dengan bahan dasar kayu yang telah semi permanen, terlihat dari pondasi dasar panggungnya yang menggunakan beton. rumah-rumah yang ada di Kota Maksum sebelum kemerdekaan banyak yang merupakan rumah panggung. Namun, telah banyak juga rumah batu bergaya Eropa yang ditinggali oleh para bangsawan, seperti rumah Tengku Pangeran Bendahara Amiruddin yang ada di simpang jalan Amaliun dan rumah Permaisuri Tengku Khadijah (istri sultan) yang masih ada sampai sekarang di ujung gang Mansun.

Rumah bergaya Eropa dan tidak menunjukkan gaya rumah panggung khas Melayu yang berbahan dasar kayu dan beratap nipah atau rumbia. Rumah-rumah pejabat kerajaan kebanyakan terletak di sekitar jalan Amaliun dengan ukuran yang besar dan megah dengan pekarangan yang luas. Bangunan-bangunan lain di sekitar kawasan seperti Balai Kerapatan, Istana Maimoon, dan Mesjid Raya Al-Manshun juga telah menunjukkan adanya pengaruh budaya luar seperti Eropa dan Timur Tengah dari segi arsitektur.Dengan bangunan yang relatif megah, maka dapat dideskripsikan bahwa daerah Kota Maksum merupakan kawasan elite di kota Medan, tempat tinggal para bangsawan yang dapat disejajarkan dengan Kota Gede di Yogyakarta

Upacara-upacara adat di Istana Maimoon merupakan suatu acara resmi kerajaan yang melibatkan masyarakat, baik dari kalangan bangsawan maupun dari kalangan masyarakat biasa.Pada acara-acara tertentu, seperti Penabalan Putera Mahkota dan Penabalan Raja, perkawinan, dan lain-lain diadakan acara keramaian 
yang melibatkan segenap masyarakat. Upacara tidak hanya diperuntukkan bagi masayarakat Kota Maksum, tetapi juga masyarakat Raja dari daerah manapun yang boleh ikut meramaikan acara dengan turut hadir di Istana. Upacara-upacara adat yang diselenggarakan oleh keluarga Kesultanan merupakan bentuk aktivitas budaya bagi masyarakat Kota Maksum yang sebagian besar merupakan kaum bangsawan. Sebagai pewaris identitas Melayu, sultan dan petinggi kesultanan menunjukkan identitas ini dengan penggunaan adat Melayu dalam upacara-upacara resmi.

Mengkaji aktivitas budaya di Kota Maksum tidak dapat dipisahkan dari kesenian-kesenian Melayu yang diwariskan turun-temurun dan hampir berlaku diseluruh daerah-daerah Melayu yang lain. Seorang tokoh bangsawan dari Kota Maksum juga memberikan kontribusi bagi perkembangan kesenian Melayu. Beliau adalah Tengku Harun Al-Rasyid, anak dari Sultan Makmun Al-Rasyid yang menjabat sebagai Tengku Perdana Mentri Deli sejak 1 Februari 1923. Tengku Harun merupakan seniman yang banyak menciptakan lagu-lagu Melayu yang masih populer hingga masa kini seperti "Pulau Puteri” dan "Serampang Duabelas". Selain menciptakan lagu, beliau juga mahir memainkan alat musik seperti gendang Melayu, harmonika, biola, dan lain sebagainya serta dikenal pula sebagai penari langgam Melayu yang mahsyur.

Sama seperti musik-musik tradisional dari banyaknya suku bangsa di Indonesia, Musik Melayu tidaklah diwariskan dalam bentuk notasi seperti halnya musik Barat. Musik yang diciptakan tidak ditulis dan diwariskan secara informal sehingga menjadi oral tradisi didalam kebudayaannya. Sejak mendapat pengaruh dari luar, alat musik dan teater Melayu telah banyak dipengaruhi oleh budaya asing, seperti alat musik akordion, bass, piano dan biola yang sering digunakan dalam pertunjukan-pertunjukannya. Akibatnya, pengaruh instrumen musik barat yang masuk secara perlahan merubah keaslian musik Melayu. instrumen akordion merupakan contoh alat musik Eropa (Portugis) yang khas dalam musik-musik Melayu. Bahkan akordion dan biola termasuk dalam benda-benda peninggalan kesultanan Deli yang di pamerkan di Istana Maimoon sekarang ini.

Pertunjukan yang sangat populer di kalangan bangsawan dan rakyat Deli pada tahun-tahun 1900-an adalah ronggeng Melayu, ketoprak, ludruk, pertunjukan tarian seperti Zapin dan Serampang Dua Belas, pertunjukan musik dan lagu 
Melayu, serta pertunjukan teater bangsawan dan makyong. Sultan-sultan juga mendatangkan kelompok-kelompok ronggeng dari Semenanjung Melayu, (tampaknya di Deli hanya kelompok ronggeng dari Pinang, kemungkinan besar sebuah kelompok Tionghoa, yang dapat melakukan pertunjukan di istana) dan menjadi penyandang dana kelompok-kelompok teater yang secara umum disebut bangsawan atau opera Melayu.

Pada acara pasar malam atau hajatan, tarian danronggeng Melayu hampir selalu dipertunjukkan. Tidak hanya pada acara-acara khusus, ronggeng Melayu juga sering di panggil ke istana untuk menghibur sultan dan pejabat belanda. Kesenian ronggeng Melayu tidak sama dengan ronggeng Jawa. Perbedaannya terletak pada seni berbalas pantun. Pantun-pantun yang dilantunkan berkisah tentang percintaan, nasihat, hingga ratapan kepada Tuhan. Selain itu, tidak dibenarkan penari laki-laki dan penari perempuan saling bersentuhan. Ronggeng ini mulai ditinggalkan pada masa pendudukan Jepang dikarenakan masuknya unsurunsur negatif dengan menyusupkan kegiatan prostitusi untuk melayani tentara Jepang.

Seni pertunjukan lainnya yang sering di nikmati masyarakat Kota Maksum adalah makyong dan bangsawan. Teater makyong lebih tradisional dari pada bangsawan. Makyong terpengaruh oleh budaya Hindu dan Budha dengan cerita tentang kebangsawanan raja-raja dan unsur legenda dunia Dewa. Teater ini biasanya dipertunjukkan saat ulang tahun raja dan pesta perkawinan. Fungsinya untuk menghibur para bangsawan dan juga rakyat awam. Sementara bangsawan merupakan seni teater gaya modern yang mirip dengan opera namun dipengaruhi oleh peradaban Islam. Teater ini berakar dari wayang Parsi yang dibawa pada akhir abad ke-19 ke Pulaupinang oleh para pedagang India dan Gujarat. Mereka membawa berbagai cerita dari Timur Tengah dan menyajikannya dalam bahasa Hindustan. Tokoh utama yang menyebarkan dan mengembangkan teater bangsawan adalah Mamak Manshor dan Mamak Pushi. Kumpulan bangsawan mereka ini melalangbuana sampai ke Sumatera dan Jawa, yang dapat dilihat pengaruhnya sampai kini pada ketoprak Jawa. Bangsawan ini mencapai zaman keemasannya dari awal sampai pertengahan abad ke 20, yang melibatkan masyarakat Melayu, India, maupun China di Asia Tenggara. Kumpulan bangsawan 
yang pertama menjejakkan kakinya ke Sumatera dibawa oleh Mamak Manshor atas undangan Sultan Deli di Medan. Sejak itu, muncullah beberapa kumpulan teater bangsawan seperti Indera Ratu dan Opera Miss Ribut, Dardanella, dan lain-lain.

Teater bangsawan yang dipertunjukkan di Deli membawakan cerita-cerita tentang Raja dan kesetiaan rakyat sehingga teater ini dipakai sebagai alat propaganda untuk menanamkan kesetiaan rakyat pada rajanya. Musik yang digunakan pada teater ini pada dasarnya adalah musik Arab dan India, namun kemudian menjadi musik Melayu yang dilengkapi dengan instrumen Eropa.Masyarakat Kota Maksum biasa menikmati acara-acara hiburan tersebut di beberapa tempat. Terkadang di Istana ketika ada perayaan-perayaan tertentu, kadang pula di Lapangan umum di dekat Simpang jalan Amaliun dan jalan Raja, dan juga di Lapangan Umum di sekitar jalan Laksana. Acara-acara yang digelar merupakan acara kesenian yang telah dijelaskan di atas. Bahkan di lapangan umum sekitar jalan Laksana diadakan acara hiburan setiap malam rabu dan malam minggu. Pertunjukannya beragam, terkadang menampilkan ronggeng, ludruk, keroprak dan lain sebagainya.

\section{E. Dampak Revolusi Sosial Bagi Masyarakat Kota Maksum}

Kehidupan para bangsawan dan statusnya sebagai penguasa berakhir dengan peristiwa revolusi sosial yang menuntut dihapuskannya sistem pemerintahan monarchi dan segala yang terkait dengannya kemudian dilebur dalam negara Republik Indonesia .Hal ini membawa dampak terhadap masyarakat bangsawan di seluruh penjuru, tak terkecuali masyarakat bangsawan yang ada di Kota Maksum. Hubungan yang baik antara pihak kolonial dengan kesultanan Deli dianggap sebagai sikap pro Belanda sehingga muncul anggapan bahwa pihak kesultanan berpotensi menjadi sekutu dalam usaha Belanda merebut kembali Indonesia sebagai jajahannya. Dengan dalih kesenjangan-kesenjangan sosial antara kaum bangsawan yang hidup dalam kemewahan dengan rakyat jelata terutama buruh perkebunan yang berada dalam kemiskinan dijadikan sebagai pemicu meletusnya revolusi .Semua yang berhubungan dengan keluarga raja atau bangsawan diburu untuk disingkirkan dan dibunuh tanpa perikemanusiaan. 
Masyarakat Kota Maksum banyak yang melarikan diri ke istana Maimoon untuk berlindung karena hanya itulah tempat terdekat yang dirasa aman oleh mereka. Istana Maimoon selamat dari penjarahan dan pembakaran karena dijaga oleh tentara bayaran Inggris (Gurkha) hingga dapat berdiri kokoh hingga saat ini.Rumah-rumah yang ditinggalkan di Kota Maksum dijarah, hampir tidak ada kekayaan yang sempat diselamatkan. Setelah dijarah, bangunan-bangunan yang ada di sana dibakar habis, termasuk istana Puri dan Istana Tengku Besar yang ada dijalan Puri dan Amaliun. Hingga saat ini, tidak terlihat lagi jejak-jejak kesultanan di Kota Maksum karena peristiwa revolusi sosial ini satu peradaban hilang di Sumatera Timur khususnya di Medan. Peninggalan satu-satunya yang masih tersisa adalah rumah permaisuri Khadijah yang berada di ujung Gang Mansun dan kini telah menjadi rumah masyarakat.

Istana Maimoon berubah seketika menjadi tempat pengungsian yang sangat ramai dipadati oleh kalangan bangsawan. Mereka mendirikan bangsal-bangsal yang memanjang dibelakang istana untuk ditinggali hingga keadaan dianggap aman. Selama masa rawan, mereka tidak keluar dari area istana. Pasokan makanan dikirim oleh tentara Inggris dalam jumlah besar sehingga kebutuhan makanan dapat terpenuhi. Mereka menyebutnya sebagai revolusi sosial yang sejatinya hanya untuk mengajak Pemerintahan Kesultanan agar bergabung dengan Republik Indonesia dan mengakui keberadaannya sebagai pemerintahan baru merdeka dari Penjajah Belanda.Tindakan brutal yang dilakukan atas nama rakyat dan negara merdeka seungguhnya sesuatu yang berlebihan tanpa memberi kesempatan bagi pihak Kerajaan untuk partisipatif.Gerakan yang begitu cepat dan tak terkontrol telah memakan peradaban satu etnis yakni Melayu di seantero Sumatera Timur dengan struktur sosial yang terbangun dalam satu sistem pemerintah Kesultanan yang dinilai oleh penggerak kerusuhan sebagai pro Kolonial zonder perundingan yang bermartabat dengan pihak Kesutanan sebagai Institusi yang mandiri dalam masyarakat Melayu. Gerakan yang disebut gerakan rakyat telah meluluhlantakkan system sosial masyarakat Melayu Sumatera Timur.

\section{PENUTUP}


Sebagai ibukota kesultanan Deli yang dipindahkan dari Labuhan karena letaknya berada di dataran rendah dan rawan banjir ,kawasan Kota Maksum menjadi pilihan secara ekonomi dan politik yang membuka peluang Medan berkembang mencapai kemakmuran lewat perluasan perkebunan dan pemusatan kegiatan administrasi perkebunan di tengah kota . Dengan dipindahkannya kantor kebun Nienhuys dan ibukota keresidenan Sumatera Timur, kemajuan Medan sebagai pusat ekonomi mendorong Hindia Belanda untuk membangun kotapraja yang merupakan cikal bakal bagi kota Medan dewasa ini. Hubungan antara Sultan Deli dan Pemerintah Kolonial terjalin lewat politik kontrak dalam mengolah lahan perkebunan telah membuka peluang Belanda untuk menguasai tanah yang semula merupakan hak Kerajaan.

Pengunaan lahan oleh Belanda memungkinkan Sultan mendapat bantuan dan konpensasi dari pemerintah kolonial dalam pembangunan kawasan Swapraja Deli dalam bentuk pembangunan kotapraja yaitu Gemeente Fonds.Perpindahan Ibukota kerajaan Deli ditandai dengan dibangunnya istana Maimoon pada $1888 \mathrm{M}$ dan diselesaikan pada 1891. Pembentukan wilayah Swapraja dilanjutkan dengan membangun bangunan-bangunan penting lain seperti Istana Puri pada 1905, mesjid raya Al-Manshun pada 1906, taman Sri Deli, kerapatan serta perkampungan sultan serta kerabatnya.Nama Kota Maksum berarti “terpelihara oleh dosa”. Sebagai kawasan pemukiman sultan beserta kerabatnya, Kota Maksum dianggap sebagai kawasan suci dan tidak dibenarkan ditempati orang-orang non muslim. Kota Maksum dihuni oleh beberapa suku,yaitu Melayu sebagai masyarakat dominan, Mandailing sebagai perantau yang menduduki jabatan pemerintahan, perantauan Minangkabau, serta Jawa. Penduduk yang tinggal di Kota Maksum terstruktur berdasarkan stratifikasi sosial dengan status sosial teratas sultan sebagai pemimpin tertinggi, kemudian bangsawan bergelar jabatan dan suksesi. Pejabat kesultanan non bangsawan, bangsawan bergelar suksesi dan strata terbawah yaitu rakyat jelata.

Dalam aktivitas politik di Kota Maksum, masyarakat yang tinggal di sana merupakan pejabat yang membantu sultan dalam menjalankan pemerintahannya. Dikawasan ini, berlaku hukum sultan yang didasarkan kepada adat dan Islam. dengan penegakan hukumnya lembaga peradilan swapraja dibantu polisi.dalam segi arsitektur didominasi rumah-rumah panggung yang terbuat dari kayuMeski 
begitu, beberapa bangunan menggambarkan adanya pengaruh budaya asing ddengan ciri bahan bangunan batu bata dan atap genteng.Jika dilihat dari bangunanbangunan peninggalan kesultanan Deli di sekitar Kota Maksum, maka dapat dilihat adanya pengaruh Eropa dan Timur Tengah nannya.

Aktivitas budaya masyarakat Kota Maksum dapat dilihat dari beberapa upacara besar di istana Maimoon yang turut melibatkan kaum kerabat dan rakyat kebanyakan. Upacara adat yang biasa dilakukan di istana Maimoon antara lain mencukur dan mengayun anak bangsawan yang lahir, sunat rasul, penabalan putra mahkota, pernikahan bangsawan, penabalan raja, raja mangkat serta upacara menjunjung duli pada hari raya Idul Fitri dan Idul Adha yang melibatkan hubungan langsung antara sultan dan masyarakatnya. Upacara-upacara adat ini biasanya menghadirkan keramaian dengan pasar malam dan acara hiburan yang diadakan jika berkenaan dengan acara suka cita seperti penabalan putra mahkota dan perkawinan. Pada acara-acara keramaian yang dilakukan pihak kerajaan, biasanya dihadirkan beberapa kesenian sebagai penghibur rakyat, seperti ronggeng, seni tari Melayu, dan teater makyong serta bangsawan .Revolusi sosial yang melanda Kerajaan di Pantai Timur Sumatera Utara telah menghilangkan satu peradaban yang membuat etnis Melayu kehilangan peran sosial budaya di lingkungannya sendiri, Tragedi ini adalah bencana peradaban bagi etnis Melayu yang memerlukan penyembuhan dan bentuk penampilan identitas yang lebih elegan secara partisipatif di semua lini kehidupan sosial budaya ke depan.

\section{DAFTAR REFERENSI}

Abdurrahman, Dudung. (2007). Metodologi Penelitian Sejarah. Yogyakarta: ArRuzz Media

Avan, Alexander. (2012). Parijs van Soematra. Medan:Reinmaker Publishing

Colombijn, Freek, dkk. (2015). Kota Lama Kota Baru, Sejarah Kota-Kota di Indonesia. Yogyakarta: Penerbit Ombak

Dja'far, Fadlin Muhammad, B.S., A. Zaidan, dan Takari, Muhammad. (2012).Sejarah Kesultanan Deli dan Peradaban Masyarakatnya. Medan: USU Press

Koestoro, Lucas Partanda, dkk. (2013). Medan, Kota di Pesisir Timur Sumatera dan Peninggalan Tuanya. Medan: Balai Arkeologi Medan

Pelly, Usman. (1998). Urbanisasi dan Adaptasi, Peranan Misi Budaya Minangkabau dan Madailing. Jakarta: LP3ES

Perret, Daniel. (2010). Kolonialisme dan Etnisitas, Batak dan Melayu di Sumatera Timur. Jakarta: KPG (Kepustakaan Populer Gramedia 
Reid, Anthony. (2011). Menuju Sejarah Sumatera, Antara Indonesia dan Dunia. Jakarta: Yayasan Obor Indonesia

Sinar, Tuanku Luckman dan Syaifuddin. (2002). Kebudayaan Melayu Sumatera Timur. Medan: USU Press

Sinar, Tuanku Luckman. (2006).Bangun dan Runtuhnya Kerajaan Melayu di Sumatera Timur. Medan: yayasan Kesultanan Serdang 